\title{
SPRINKLER IRRIGATION SYSTEM DESIGN AND EVALUATION BASED ON UNIFORMITY
}

\author{
${ }^{1}$ Kamal .H Amer, ${ }^{1}$ M.A. Aboamera, ${ }^{1}$ A.H.Gomaa, ${ }^{2}$ Sobhy B. Deghedy
}

\begin{abstract}
A selected rotating sprinkler was tested in radial test within 100 to 300 $\mathrm{kPa}$ under nozzle \#8 with $25^{\circ}$ trajectory angle and \#3 with $11^{\circ}$ and $25^{\circ}$ trajectory angles. $K$ - Rain 75 pop-up sprinklers were selected due to having 12 different nozzle trajectory angles. Sprinkler discharge application rate, and pattern radius were measured at different operating pressures in individual test. For 300kPa high distribution uniformity was obtained for nozzle \#8 with $25^{\circ}$ trajectory angle in square and rectangular layouts. Square layout achieved distribution uniformity higher than rectangular layout for overlapping 100and $80 \%$. Friction loss for a given pipe length was found in designing optimal main ,sub-main and lateral diameters under optimal nozzle angle, pressure, layout and overlapping.
\end{abstract}

Key words: irrigation sprinkler system design, evaluate uniformity distribution coefficient, nozzle discharge, optimal operating pressure.

\section{INTRODUCTION}

7 he uniformity distribution pattern is a measure of how evenly the sprinkler system applies water over the irrigated area. Many

1 factors that donate non-uniformity are regarded to sprinkler performance and hydraulic variation along lateral. Hegazi et al. (2007) found that, optimal layouts were $40 \%$ to $60 \%$ from diameter of throw in square layout in rang of trajectory angle in between with $15^{\circ}$ and $30^{\circ}$. Amer (2006) found that, the high degree of water distribution uniformity was obtained from sprinkler layouts as $60 \%$ from diameter of throw in square layout and in rang from 50 to $70 \%$ from diameter of throw in rectangular.

$*^{* 1}$ Ass.Prof. ,Agric.Eng.Fac.of agric. Menoufia University
${ }^{2}$ Eng. ,Agric.Eng.,Sept.,Fac.of agric. Menoufia University 
For impact sprinklers, spacing was recommended to be as $50 \%$ from diameter of throw in square layout and in rang from 50 to $60 \%$ from in rectangular. Triangular layout achieved higher uniformity than square even for the same area.

Ascough and Kiker (2002) studied the application uniformity of different irrigation systems in five sugar-growing regions in South Africa. The average low- quarter uniformity (DU) of center pivot, dragline, micro irrigation, floppy and semi permanent sprinkler systems was $81.40 \%, 60390 \%, 72.70 \%, 67.40 \%$ and $56.90 \%$ respectively. Amer (2006) found that, pressure loss should not exceed $10 \%$ of the nozzle operating pressure as used in selecting lateral length based on set a pressure regular at the inlet of each lateral.

Keller and Bliesner (1990) configured that, water distribution pattern in low wind conditions was described in five categories based on sprinkler. They recommended that, spacing among sprinklers should give acceptable application uniformities when a realistic effective diameter of throw is used. Each category has its spacing based on square, triangular and rectangular, layouts ranges from 50 to $80 \%$ from diameter of throw. Generally, spacing can be used as $50 \%$ of the effective diameter in square layout, $62 \%$ in equilateral triangular and 40 to $67 \%$ in rectangular based on average wind speed. Profile types A and $\mathrm{B}$ are characteristic of sprinklers having two nozzles. Profile types $\mathrm{C}$ and D are characteristic of single nozzle sprinklers at recommended pressure. Profile type E is generally produced with gun sprinklers or sprinklers operating at pressures lower than those recommended for the nozzle size, as showed in Table 1. 


\begin{tabular}{|c|c|c|c|c|}
\hline \multicolumn{2}{|c|}{ Sprinkler profile } & \multicolumn{3}{|c|}{$\begin{array}{c}\text { Optimum spacing as a percentage of } \\
\text { diameter }(\%)\end{array}$} \\
\hline Type & Shape & Square & Triangular & Rectangular \\
\hline A & & 50 & 50 & $50 \times 60$ to 65 \\
\hline B & & 55 & 66 & $40 \times 60$ \\
\hline $\mathrm{C}$ & & 60 & 65 & $40 \times 60$ to 65 \\
\hline $\mathrm{D}$ & & $\begin{array}{l}40-70 \\
\text { (Fair) }\end{array}$ & 70 to 75 & $40 \times 75$ to 75 \\
\hline $\mathrm{E}$ & & 40 & 80 & $40 \times 80$ \\
\hline
\end{tabular}

Distribution from an individual sprinkler is simulation, in most cases by a precipitation linearly decreasing away from the center (El-Awady et al., 2003). Sprinklers are usually spaced at $50 \%$ of the wetted diameter around individual heads. Distribution uniformity is usually assessed on overlapped patterns to help determining the critical irrigation water requirement. Li and Kawano (1998) described a relationship between discharge and pressure for an orifice nozzle as follows :

$$
\mathrm{Q}=\mathbf{c} \times \mathbf{2} \mathbf{2 \mathrm { gH }})^{\mathrm{X}}---(\mathbf{1})
$$

where: $\mathrm{Q}$ is the nozzle discharge rate $\left(\mathrm{m}^{3} / \mathrm{sec}\right), \mathrm{A}$ is the orifice cross sectional area $\left(\mathrm{m}^{2}\right), \mathrm{g}$ is the gravitational acceleration (9.81 $\left.\mathrm{m} / \mathrm{sec}^{2}\right), \mathrm{H}$ is the sprinkler pressure head $(\mathrm{m}), \mathrm{c}$ is the discharge coefficient and $\mathrm{x}$ is the discharge exponent.

Christiansen (1942) indicated of adequate operating pressure, low wind speed, proper speed rotation and proper sprinkler layout. Higher water uniformity may be achieved distribution pattern that define as a measure of low evenly the sprinkler applies water over the irrigated area is an 
important parameter to plan, design and, manage sprinkler irrigation system. Christiansen's uniformity coefficient (CU) defined as follows:

$$
\mathbf{C U}=\mathbf{1}-\frac{\sum_{\mathbf{i}=\mathbf{1}}^{\mathbf{N}}\left|\mathbf{X}_{\mathbf{i}}-\overline{\mathbf{X}}\right|}{\mathbf{N} \overline{\mathbf{X}}}---(\mathbf{2})
$$

where: $\boldsymbol{C} \boldsymbol{U}$ is the Christiansen's uniformity coefficient, $\mathrm{X}$ is the water depth collected by catch cans in $\mathrm{mm}, \mathrm{X}^{-}$is the mean water depth collected in all catch cans in $\mathrm{mm}$, and $\mathrm{N}$ is the total number of catch cans.

Warrick and Yitayew (1988) figured out that, uniformity coefficient (CU)with normal distribution is a function of coefficient of variation as follows:

$$
\mathrm{CU}=\mathbf{1}-\mathbf{0 . 7 9 8 C V}---(3)
$$

where: $\boldsymbol{C U}$ is the uniformity coefficient, and $\mathrm{CV}$ is the coefficient of variation of water distribution depth.

El-Sherbeni (1994) found that, when riser height increased from 50 to $150 \mathrm{~cm}$, the coefficient of uniformity $(\mathrm{CU})$ values decreased from $78.5 \%$ to $70.0 \%$ for Rain Bird and from $84.60 \%$ to $65.0 \%$ for developed sprinkler under the same operating pressure of $150 \mathrm{kPa}$ and nozzle size $2.4 \mathrm{~mm}$.

Aboamera and Sourell(2003) attempted to achieve good water distribution for a new sprinkler nozzle called floppy sprinkler at an acceptable irrigation intensity. They found that, the average Christiansen coefficient of uniformity (CU) and distribution uniformity (DU) were $88.01 \%$ and $80.94 \%$ respectively for $1.5 \mathrm{~m}$ sprinkler height and $200 \mathrm{kPa}$ operating pressure.

Keller and Bliesner (1990) defined the ratio of water distribution uniformity as mean depth caught on the one forth of the field receiving the least amount to mean depth caught on the entire area. Distribution uniformity (DU) for sprinkler irrigation system can be formulated as a normal distribution as follows:

$$
\mathrm{DU}=1-1.27 \mathrm{CV}---(4)
$$

Irrigation Testing and Research Center, ITRC, (1991) suggested that, the distribution of uniformity (DU) values were excellent (75.0 85.0),good (65.0-75.0), and poor $(5.0-65.0 \%)$ for the multi -stream, 
single - stream rotor and fixed spray -sprinkler, and single -stream rotor respectively.

Duckes and Perry (2006) studied the uniformity along the length of a center pivot and a linear move irrigation system. They found that, the averaged values of the low quarter distribution uniformity were $90.0 \%$ and $74.0 \%$ for the center pivot and the linear move irrigation system respectively.

From Watters and Keller (1978), the Darcy -Weisbach equation for smooth pipes with turbulent flow in trickle irrigation systems was combined with the Blasius equation for the friction factor which gives accurate prediction for frictional head loss. The friction head loss for a given pipe length with a constant input and output discharge can be estimated (Amer,2006).

$$
\Delta \mathbf{H}=K_{1} \frac{\mathbf{Q}^{1.75}}{D^{4.75}} \times \mathbf{L}---(5)
$$

where: $\Delta \mathrm{H}$ is the friction loss in $\mathrm{m}, \mathrm{Q}$ is the inlet flow rate in $\mathrm{m}^{3} / \mathrm{dec}$ at the beginning of each lateral or sub main length $\mathrm{L}$ with inside diameter $\mathrm{D}$ both are in $\mathrm{m}$, and $\mathrm{K}_{1}$ is the friction factor which depends on water temperature, viscosity and protrusion. $\mathrm{K}_{1}$ equals $\mathbf{7 . 9 4} \times \mathbf{1 0}^{-4}$ with no protrusion at $20^{\circ} \mathrm{C}$.

For lateral or sub main line with multiple outlets along the line which flow is non -uniform, an equation is developed based on the change of friction loss due to pipe length considering inconstantly of water flow throughout outlets. Therefore, the friction loss $\left(\Delta \mathrm{H}_{\ell}\right)$ at any section of lateral or sub main line can be derived as follows (Amer,2006):

$$
\Delta \mathrm{H} \ell=\frac{K_{1}}{2.75} \times \frac{\alpha \times Q^{1.75}}{D^{4.75}} \times\left\{1-\left(1-\frac{\ell}{L}\right)^{2.75}\right\}---(6)
$$

where: $\left(\Delta \mathrm{H}_{\ell}\right)$ is the friction loss head at a length $\ell$ measured from inlet, $\alpha$ is the equivalent barb coefficient. Considering inlet lateral connector is treated as a barb.

\section{MATERIALS AND METHODS}

Schematic diagram of $\mathrm{k}$ - rain pop - up sprinkler characteristic was shown in Fig.1. The operating pressures which controlled by a pressure regulating valve of 200 and $300 \mathrm{kPa}$ were used to test each nozzle of sprinkler. Bourdon tube gauge manometer was fixed at the base of sprinklers and used to measure the pressure. Water flow meter was fitted after control valve to measure sprinkler discharge each test. Both 
pressure and flow meters were calibrated prior to the tests. The nozzle height was $10 \mathrm{~cm}$ above ground as recommended by most manufacturers and Zanon et al (2000).

Pattern radius for layout test for each individual sprinkler was installed using two diagonal lines north - south and east - west of catch cans at $1 \mathrm{~m}$ spacing as shown in Fig.2. The test duration was one hour. Tests were accomplished for 3 nozzles for sprinkler which is Pop - up (Krain Rps75) sprinkler (2 nozzles standard and 1 nozzle low angle nozzles of $25^{\circ}$ and $11^{\circ}$ trajectory angle). The selecting of this type of sprinkler was based on its ability to have different configurations. It has low nozzle angle and size that help to stream trajectories below fruit foliage for orchard or also in greenhouses. Sprinkler discharge, application rate and pattern radius were recorded at different operating pressures by pattern radius test, as shown in Fig.2. The catch cans were $0.119 \mathrm{~m}$ entrance diameter and $0.1 \mathrm{~m}$ height. The collected water was measured and related to its area in $\mathrm{mm} / \mathrm{h}$. In fact, the international standards for sprinkler evaluation recommended catch can diameter higher than $85 \mathrm{~mm}$ (Anonymous, 1995).

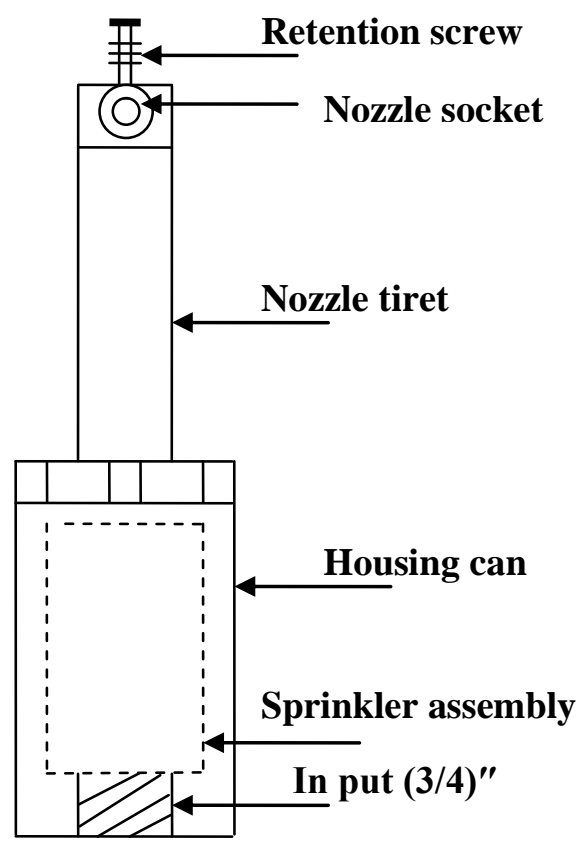

Fig.1: Schematic diagram of K- rain pop - up sprinkler characteristic 
Square, triangular and rectangular layouts for uniformity degree for sprinklers water distribution tests were simulated as shown in Fig.3. Catch cans were located at $1 \mathrm{~m}$ along and across laterals in an overlapping grid pattern Spacing between sprinklers along and across laterals was determined as 40 and $50 \%$ of the diameter of throw as spaced. These distances created overlapped percentages as $100 \%$ and $80 \%$ respectively. To find out the optimum pressure for operating sprinklers, uniformity tests were carried out in square layout at 200 and $300 \mathrm{kPa}$ for each nozzle of sprinkler for only $100 \%$ overlapped percentage. The optimum operating pressure were $300 \mathrm{kPa}$ for all nozzles and $200 \mathrm{kPa}$ for nozzle \#3 trajectory angle $25^{\circ}$ and trajectory angle $11^{\circ}$ for K-rain sprinkler.

Uniformity tests that conducted for three layouts of sprinkler under optimum operating pressures were for square, triangular and rectangular layouts as shown in Fig.3. For nozzle \#8 trajectory angle $25^{\circ}$ of sprinkler with $16 \mathrm{~m}$ diameter of throw working under $300 \mathrm{kPa}$, sprinklers were headed for both square and triangular layouts at 8 and $9.6 \mathrm{~m}$ for 100 and $80 \%$ overlapped percentages respectively. Rectangular layout was headed at $9.5 \times 8 \mathrm{~m}$ and $11.4 \times 9.6 \mathrm{~m}$ for 100 and $80 \%$ overlapped percentages respectively long $(\mathrm{L})=19 \mathrm{~m}$ and short $(X)=16 \mathrm{~m}$. For nozzle \#3 trajectory angle $25^{\circ}$ of sprinkler with $12 \mathrm{~m}$ diameter of throw working pressure $300 \mathrm{kPa}$, sprinklers were headed for both square and triangular layouts at $7.2 \mathrm{~m}$ for 100 and $80 \%$ overlapped percentages. Headed rectangular layout at $8 \times 6 \mathrm{~m}$ and $9.6 \times 7.2 \mathrm{~m}$ for 100 and $80 \%$ overlapped percentages respectively long $(\mathrm{L})=16 \mathrm{~m}$ and short $(X)=12 \mathrm{~m}$. For nozzle \#3 trajectory angle $11^{\circ}$ of sprinkler with $11 \mathrm{~m}$ diameter of throw working under $300 \mathrm{kPa}$, sprinklers were headed for both square and triangular layouts at $5.5 \mathrm{~m}$ and $6.6 \mathrm{~m}$ for 100 and $80 \%$ overlapped percentages respectively. Moreover, headed rectangular layout at $6.5 \times 5.5 \mathrm{~m}$ and $7.8 \times 6.6 \mathrm{~m}$ for 100 and $80 \%$ overlapped percentages respectively long (L) $=13 \mathrm{~m}$ and short $(\mathrm{X})=11 \mathrm{~m}$. The application depth caught in $\mathrm{mm} / \mathrm{h}$ that collected in uniformity test was categorized based on frequency. The frequency of the application depths was accumulated from maximum to minimum of water caught. 


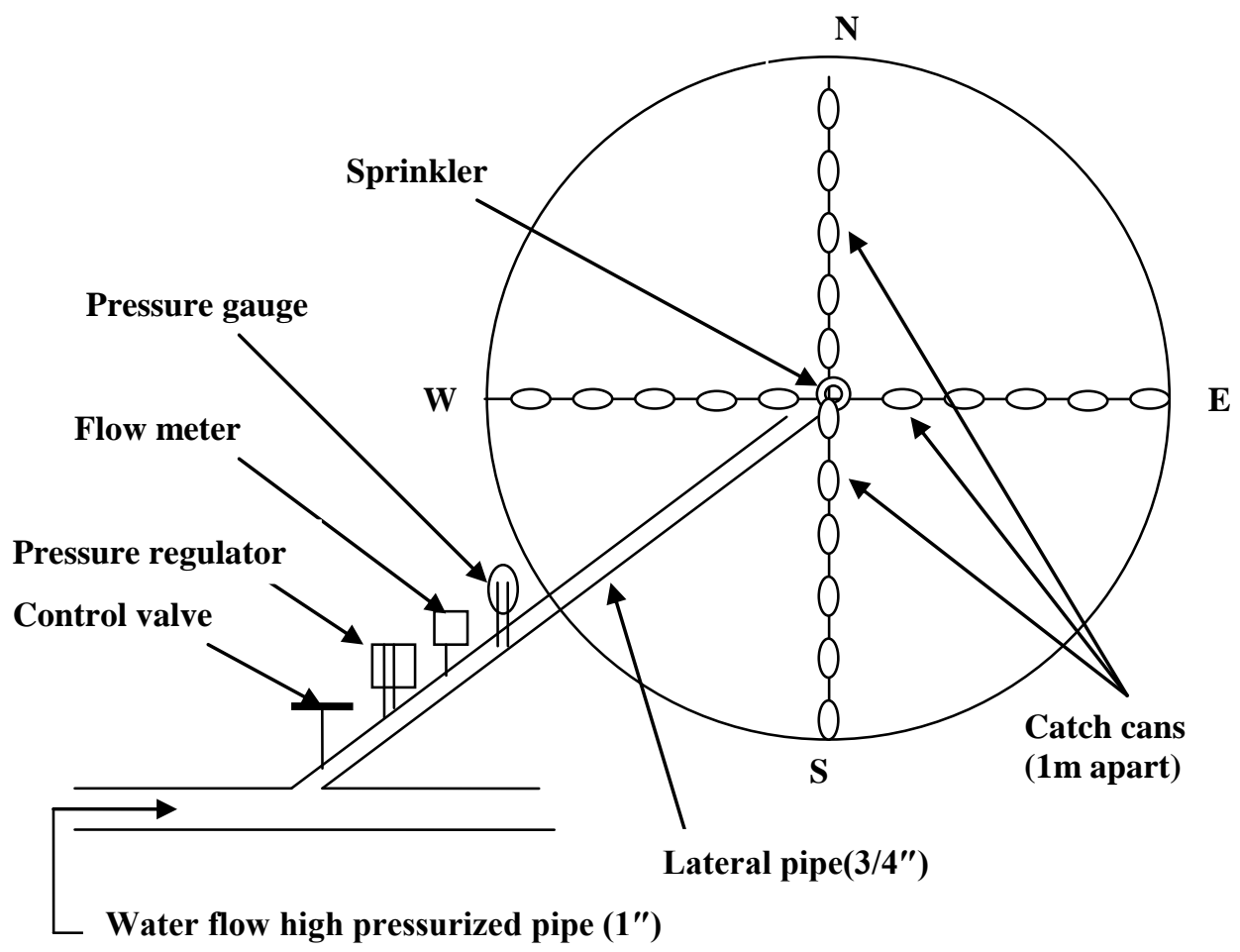

Fig.2: Pattern test layout

Application rate was determined by the following equation:

$$
\mathbf{A R}=\frac{1000 \mathbf{q}}{\mathrm{A}}---(\mathbf{7})
$$

where, AR is the theoretical application rate in $\mathrm{mm} / \mathrm{h}, \mathrm{q}$ is the sprinkler discharge in $\mathrm{m}^{3} / \mathrm{sec}$ and $\mathrm{A}$ is the served area in.

Actual irrigation application rate $\left(\mathrm{I}_{\mathrm{p}}\right)$ was determined based on average of collected water depths in layout area in catch cans per unit time as follows :

$$
I_{p}=\frac{\bar{X}}{t}---(8)
$$

where, $\left(\mathrm{I}_{\mathrm{p}}\right)$ is the actual application rate in $\mathrm{mm} / \mathrm{h}, \mathrm{X}^{-}$is the collected irrigation depth using catch cans during operating sprinkler in $\mathrm{mm}$, and $\mathrm{t}$ is the collected time in $\mathrm{h}$. 

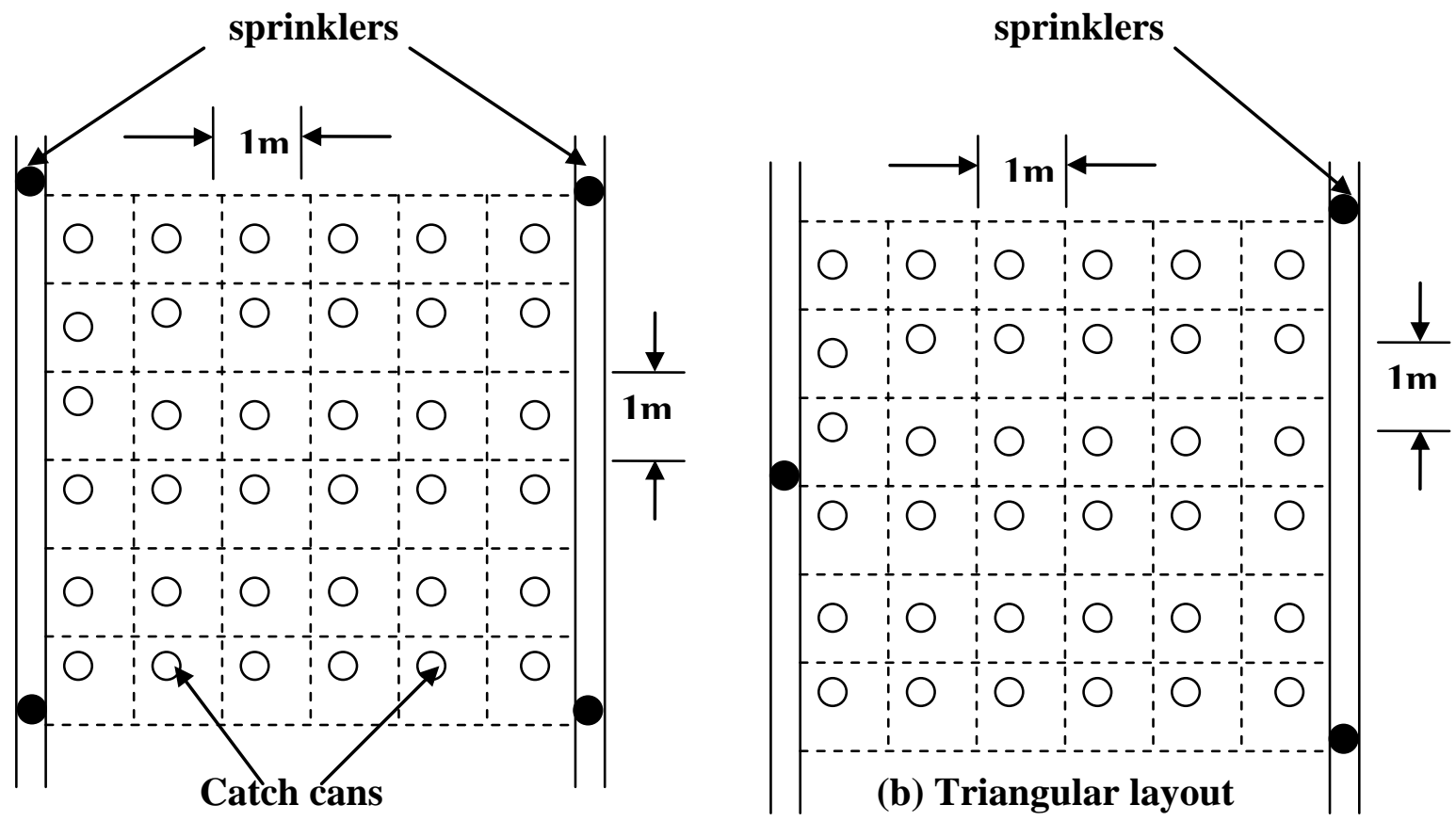

(a) Square layout

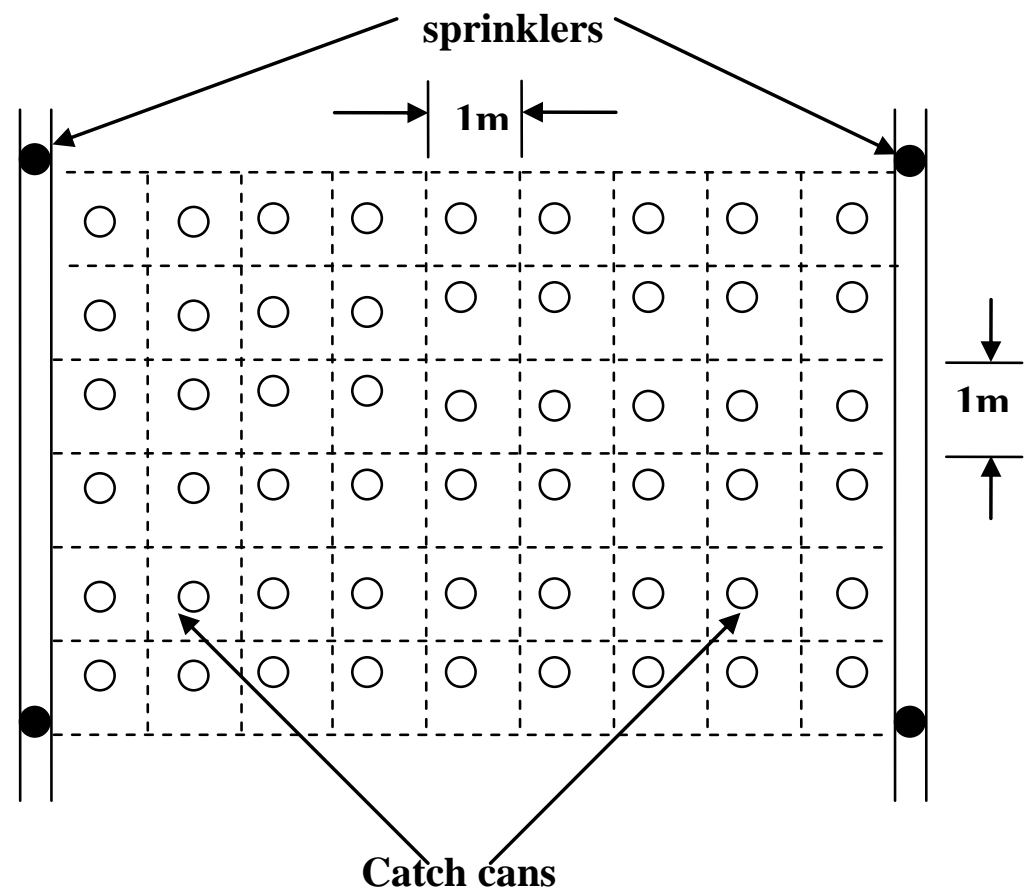

(c) Rectangular layout

Fig.3: Schematic diagram or unırormıty aıstrıbutıon tests for sprinklers layouts 
The design was conducted in Menoufia university Stadium at Sibin Elkom which dimensioned at $121 \times 55 \mathrm{~m}$ using Pop-up sprinklers, 72 sprinklers were used and 121 lateral and 4 sub main lines and single main line. Nozzles \#3 trajectory angle $25^{\circ}$ was used with wetted diameter $22 \mathrm{~m}$ and square layout under optimal pressure $300 \mathrm{kPa}$ and $100 \%$ overlapping.

Field dimension was $55 \mathrm{~m}$ wide $\times 121 \mathrm{~m}$ length, 72 sprinklers were used and 121 lateral with (20 and $25 \mathrm{~mm}$ ) inner diameter and 4 sub main lines $(50 \mathrm{~mm})$ and single inlet main line with $62 \mathrm{~mm}$ inner diameter.

The water source position with $10 \mathrm{~m} 3 / \mathrm{h}$ at half for main line and distance from the source to last sprinkler (critical length) $115.5 \mathrm{~m}$. The area were blocked to four blocks had one valve and one sub main and three lateral lines and 15 sprinklers and all lines were made from (PVC). The system used nozzle \#3 trajectory angle $25^{\circ}, 0.5 \mathrm{~m} 3 / \mathrm{h}$ discharge with wetted diameter $22 \mathrm{~m}, 300 \mathrm{kPa}$ operating pressure, square layout and $100 \%$ overlapping percentage as shown in Fig.4. Friction factor which gives accurate prediction for head, friction head loss for a given pipe length with a constant input and output discharge sprinkler was estimated for design to reach the optimal inner diameter for main, sub main and lateral lines under optimal nozzle, trajectory angle, pressure, layout and overlapping. Sprinklers in design to irrigate full cycle, but at corner it irrigate a quarter cycle and at the edges of it irrigate half cycle. During irrigation 3 sub main's valves were closed and one was opened to irrigate one block after one. Sub main line $(40 \mathrm{~mm})$ inner diameter $22 \mathrm{~m}$ long (PVC) pipe and 3 lateral lines and 15 sprinklers with distance between laterals (L) $11 \mathrm{~m}$ and with distance between sprinklers (s) $11 \mathrm{~m}$ as shown in Fig.4. Lateral lines with 5 sprinklers and $55 \mathrm{~m}$ total length (20and $25 \mathrm{~mm}$ ) inner diameter for (33 and $22 \mathrm{~mm}$ ) length respectively. The average discharge in lateral line was 2 and $1 \mathrm{~m}^{3} / \mathrm{h}$ for inner diameter 25 and $20 \mathrm{~mm}$ respectively. 


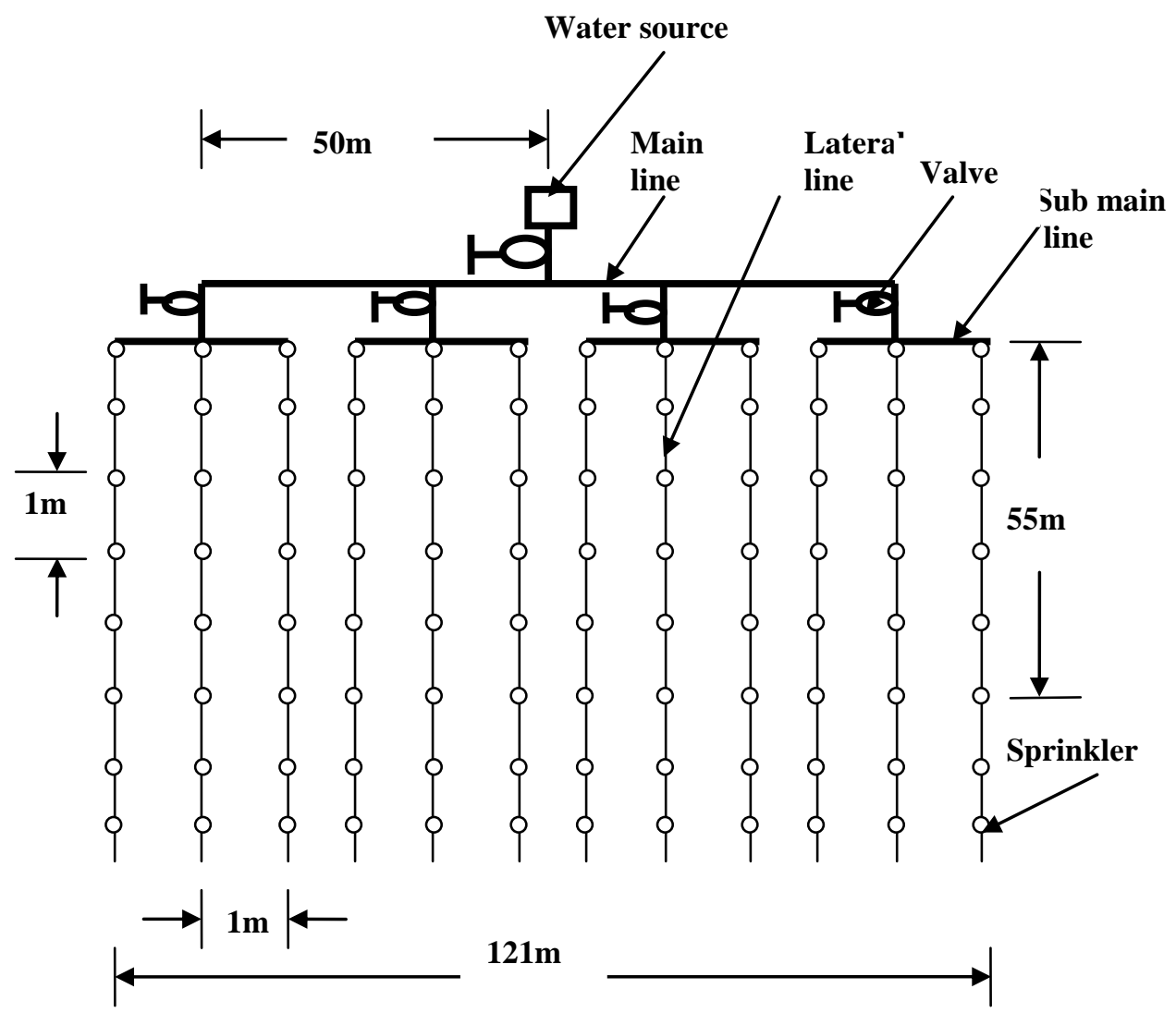

Fig.4: Sprinkler system diagram with nozzle \#3 and trajectory angle $25^{\circ}$

\section{RESULTS AND DISCUSSION}

\subsection{Water application rate}

Water application rate in $(\mathrm{mm} / \mathrm{h})$ by individual sprinkler under $200 \mathrm{kPa}$ and $300 \mathrm{kPa}$ operating pressure was found as related to distance from sprinkler in $(\mathrm{m})$. For a given operating pressure, sprinkler pattern was also plotted for different sprinkler nozzle sizes and throw angles. Different nozzle sizes were numbered as \#8 and \#3 which tested under the foregoing pressures as shown in Table 2. For a given trajectory angle, discharge rates were recorded and plotted against heads under pressures $200 \mathrm{kPa}$ and $300 \mathrm{kPa}$ for each nozzle. All trajectory heights started from the beginning point as $0.11 \mathrm{~m}$ which was the height of sprinkler nozzle. It seemed that trajectory was not significantly changed 
for the same set under any operating pressure. Water throw angle from sprinkler nozzle was almost averaged $\left(25^{\circ}\right.$ and $\left.11^{\circ}\right)$ for high pressure of $200 \mathrm{kPa}$ and $300 \mathrm{kPa}$. The throw was increased by exceeding pressure regarding to creating high jet velocity by pressure. Furthermore, wetted diameter was also increased by increased trajectory angle. Reasonably, the higher the trajectory height the bigger the throw. Inversely, throw was decreased under both low operating pressure and trajectory angle.

\section{Table2: Configuration of sprinklers with nozzle under different pressure}

\begin{tabular}{|c|c|c|c|c|}
\hline \multirow{3}{*}{$\begin{array}{c}\text { Pressure } \\
(\mathrm{kPa})\end{array}$} & \multirow{3}{*}{ Parameters } & \multirow{3}{*}{$\begin{array}{c}\text { Nozzle } \\
\text { \#8 }\end{array}$} & \multicolumn{2}{|c|}{ Nozzle \#3 } \\
\hline & & & \multicolumn{2}{|c|}{ Trajectory angle } \\
\hline & & & $25^{\circ}$ & $11^{\circ}$ \\
\hline \multirow{3}{*}{200} & Discharge $\left(\mathrm{m}^{3} / \mathrm{h}\right)$ & 1.14 & 0.41 & 0.48 \\
\hline & Throw (m) & 12.00 & 12.00 & 8.00 \\
\hline & $\begin{array}{l}\text { Application } \\
\text { rate,AR,(mm/h) }\end{array}$ & 2.51 & 0.90 & 2.39 \\
\hline \multirow{3}{*}{300} & Discharge $\left(\mathrm{m}^{3} / \mathrm{h}\right)$ & 1.47 & 0.49 & 0.51 \\
\hline & Throw (m) & 16.00 & 12.00 & 10.00 \\
\hline & $\begin{array}{l}\text { Application } \\
\text { rate,AR,(mm/h) }\end{array}$ & 1.82 & 1.09 & 1.61 \\
\hline
\end{tabular}

At operating pressure $200 \mathrm{kPa}$ nozzle $\# 8$ trajectory angle $25^{\circ}$ application rate increase in which faraway in wetted cycle of sprinkler and application rate decrease in area near sprinkler in wetted cycle in individual sprinkler test. This distribution not accepted as shown in Fig.5 and 6 , while nozzle \#3 trajectory 


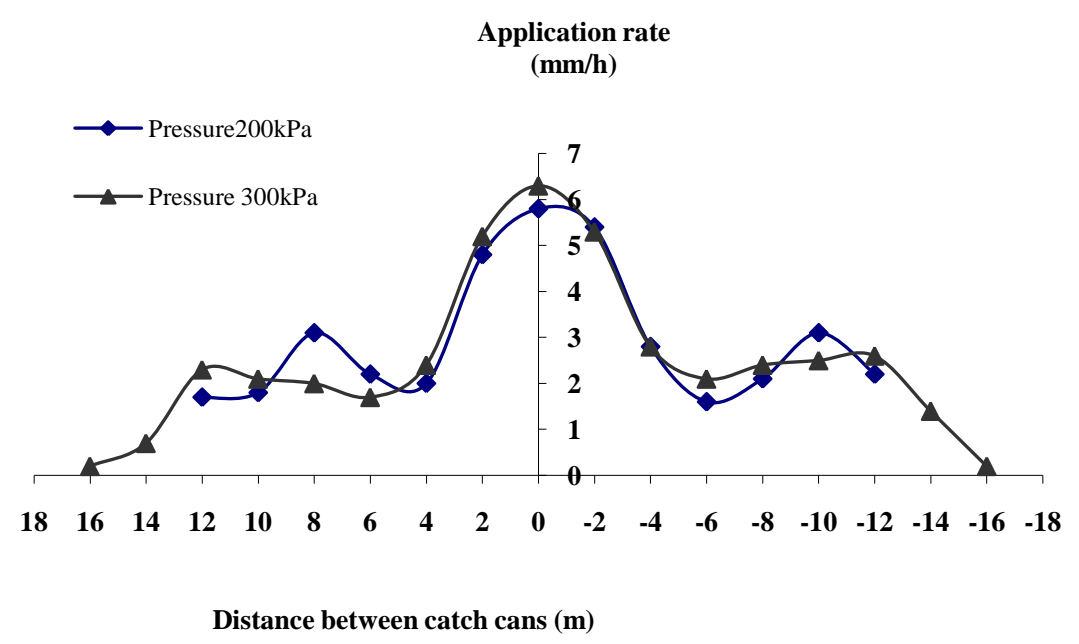

Fig.5: Individual distribution pattern for nozzle \#8H,North \& south

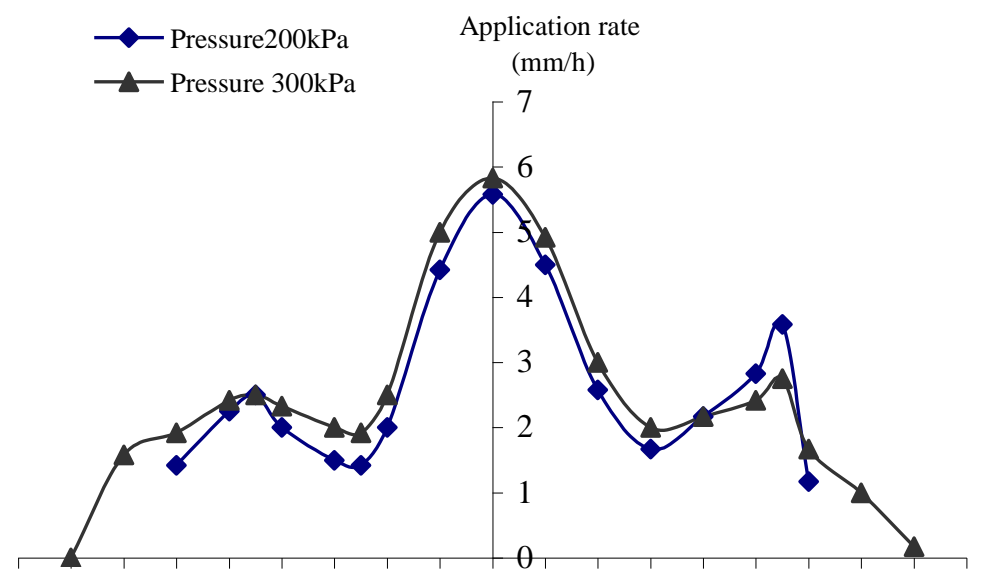

$\begin{array}{llllllllllllllllllll}18 & 16 & 14 & 12 & 10 & 8 & 6 & 4 & 2 & 0 & -2 & -4 & -6 & -8 & -10 & -12 & -14 & -16 & -18\end{array}$

Fig.6: Individual distribution pattern,nozzle \#8H.East\& West

angle $25^{\circ}$ the distribution is nearly accepted and trajectory angle $11^{\circ}$ the distribution is accepted as shown in Fig.7,8,9 and 10 respectively.

At operating pressure $300 \mathrm{kPa}$ for all nozzle application rate distributed as bell shape in wetted cycle of sprinkler in individual sprinkler test 
distributions for nozzle $\# 8$ at trajectory angle $25^{\circ}$ of sprinkler with $16 \mathrm{~m}$ throw gave good acceptable distribution as shown in Fig.5 and 6. For nozzle \#3 trajectory angle $11^{\circ}$ of sprinkler with $12 \mathrm{~m}$ and $11 \mathrm{~m}$ throw gave a very good acceptable distribution as shown in Fig.7 and 8 . Selecting the optimal range of operating pressure was not depended on analysis from radial test, but also analysis from uniformity test as in the approaching text. But that will achieve the desirable uniformity.

\subsection{Water distribution pattern}

\section{(a) Nozzle \#8 trajectory angle $25^{\circ}$}

Different water distribution patterns from nozzle \#8 at trajectory angle $25^{\circ}$ under $200 \mathrm{kPa}$ and $300 \mathrm{kPa}$ operating pressure were found and presented in Fig.5. At $200 \mathrm{kPa}$ operating pressure, the application rate was $5.5 \mathrm{~mm} / \mathrm{h}$ at the center and was $0.15 \mathrm{~mm} / \mathrm{h}$ at north and $0.54 \mathrm{~mm} / \mathrm{h}$ at south. For $300 \mathrm{kPa}$, it was $6 \mathrm{~mm} / \mathrm{h}$ at the center and was $0.30 \mathrm{~mm} / \mathrm{h}$ at north and $0.57 \mathrm{~mm} / \mathrm{h}$ at south.

The results also showed that, the higher the operating pressure the higher the wetted area because sprinkler discharge was increased. Reversely, application rate was decreased by increasing the operating pressure due to increasing wetted area, relative to increasing sprinkler discharge. Figure 6 showed different water distribution for application rate in wetted area for sprinkler as follows: (1)Pressure $200 \mathrm{kPa}$ gave $5.5 \mathrm{~mm} / \mathrm{h}$ at the center and $0.76 \mathrm{~mm} / \mathrm{h}$ at east and $0.91 \mathrm{~mm} / \mathrm{h}$ at west.(2)For 300 $\mathrm{kPa}$, it was $6 \mathrm{~mm} / \mathrm{h}$ at the center and $0.08 \mathrm{~mm} / \mathrm{h}$ at east and $0.53 \mathrm{~mm} / \mathrm{h}$ at west.

Water distribution pattern curve under $100 \mathrm{kPa}$ showed that water concentrated around and a distance away from sprinklers due to insignificant pressure. The curve produced under medium pressure of $200 \mathrm{kPa}$ showed water from nozzle settled around sprinkler and smoothly dropped from start to end of water trajectory. Curves in Figure 6 turned to be semi-trapezoid with slight peak at the middle of the throw radius. For high pressures of $300 \mathrm{kPa}$, water patterns semi-trapezoid shape.

\section{(b) Nozzle \#3 trajectory angle $\mathbf{2 5}^{\circ}$}

Figure7showed the water application rate in wetted cercal for sprinkler as follows (1) Pressure $200 \mathrm{kPa}$ gave $4.0 \mathrm{~mm} / \mathrm{h}$ at the center and 0.15 
$\mathrm{mm} / \mathrm{h}$ at north and $0.18 \mathrm{~mm} / \mathrm{h}$ at south. (2)For $300 \mathrm{kPa}$, it was $4.6 \mathrm{~mm} / \mathrm{h}$ at the center and $0.18 \mathrm{~mm} / \mathrm{h}$ at north and $0.15 \mathrm{~mm} / \mathrm{h}$ at south.

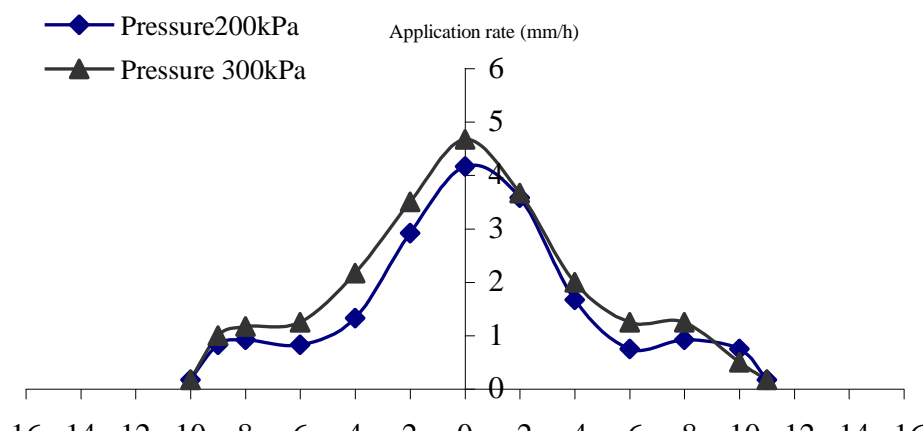

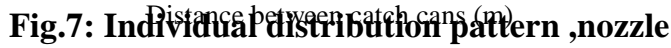
\#3.HNorth \&South

Figure 8 showed the water application rate in wetted cercal for sprinkler as follows: (1)Pressure $200 \mathrm{kPa}$ gave $4.0 \mathrm{~mm} / \mathrm{h}$ at the center and 0.08 $\mathrm{mm} / \mathrm{h}$ at east and $0.6 \mathrm{~mm} / \mathrm{h}$ at west. (2)For $300 \mathrm{kPa}$, it was $4.6 \mathrm{~mm} / \mathrm{h}$ at the center and $0.36 \mathrm{~mm} / \mathrm{h}$ at east and $0.44 \mathrm{~mm} / \mathrm{h}$ at west.

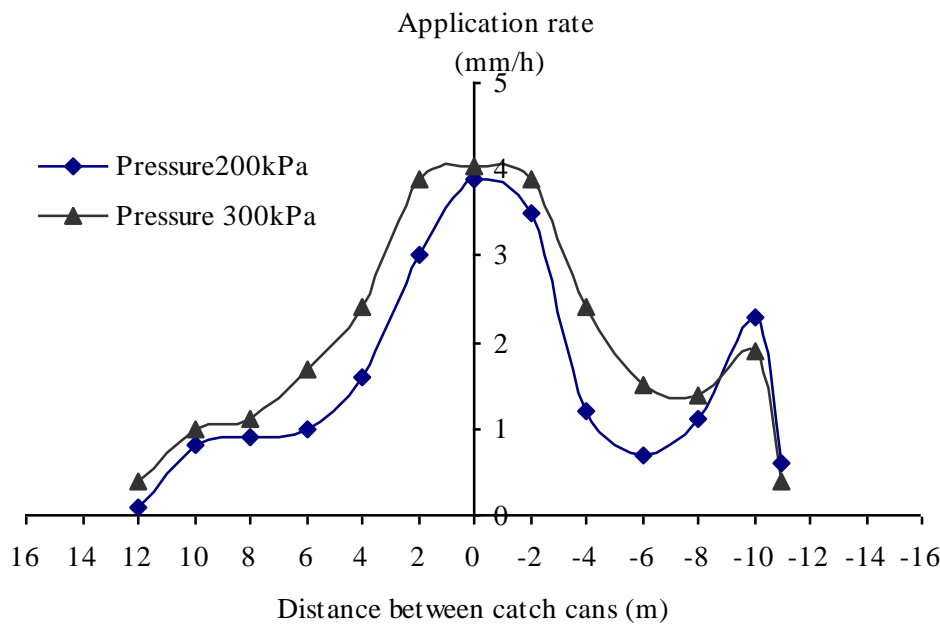

Fig.8: Individual distribution pattern,nozzle\#3H,Fast\& West

\section{(c) Nozzle \#3 trajectory angle $11^{\circ}$}

Figure 9 showed the water application rate in wetted cercal for sprinkler as follows: (1)Pressure 200kPa gave $5.2 \mathrm{~mm} / \mathrm{h}$ at the center and 1.7 
$\mathrm{mm} / \mathrm{h}$ at north and $1.76 \mathrm{~mm} / \mathrm{h}$ at south.(2)For $300 \mathrm{kPa}$, it was $5.6 \mathrm{~mm} / \mathrm{h}$ at the center and $0.05 \mathrm{~mm} / \mathrm{h}$ at north and $0.29 \mathrm{~mm} / \mathrm{h}$ at south.

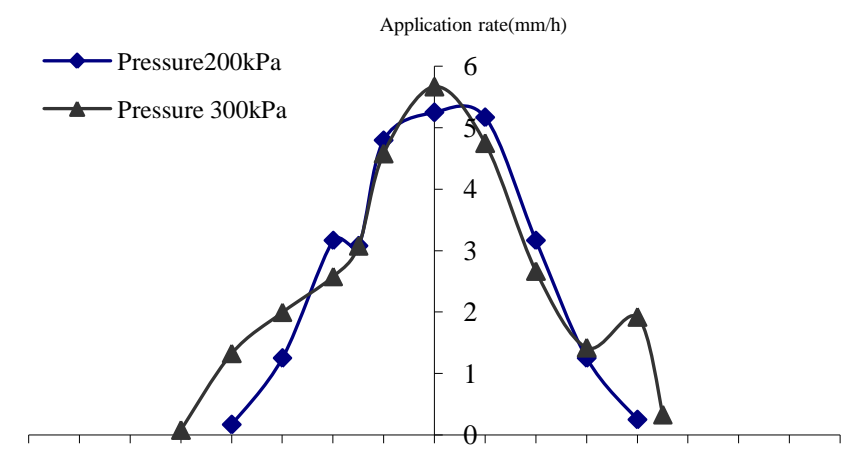

$\begin{array}{lllllllllllllllll}16 & 14 & 12 & 10 & 8 & 6 & 4 & 2 & 0 & -2 & -4 & -6 & -8 & -10 & -12 & -14 & -16\end{array}$

Distance between catch cans $(\mathrm{m})$

Fig.9: Individual distribuyion pattern,nozzle3L,North \&South

Figure 10 showed the water application rate in wetted cercal for sprinkler as follows: (1)Pressure 200kPa gave $5.2 \mathrm{~mm} / \mathrm{h}$ at the center and $0.74 \mathrm{~mm} / \mathrm{h}$ at east and $0.08 \mathrm{~mm} / \mathrm{h}$ at west. (2)For $300 \mathrm{kPa}$, it was 5.6 $\mathrm{mm} / \mathrm{h}$ at the center and $0.17 \mathrm{~mm} / \mathrm{h}$ at east and $0.02 \mathrm{~mm} / \mathrm{h}$ at west.

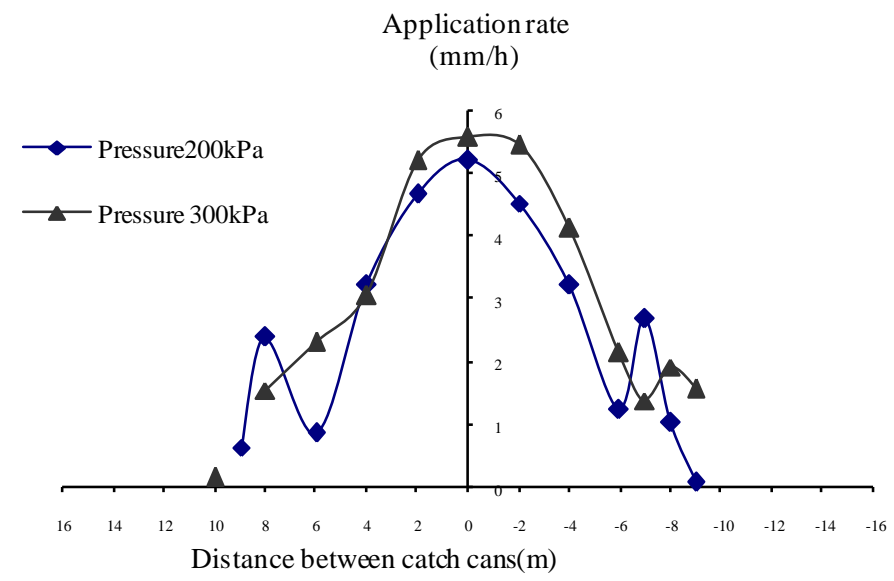

Fig.10: Individual distribution pattern, nozzle \# 3L,East \& West 
For each nozzle, sprinkler discharge $\left(\mathrm{q}\right.$ in $\mathrm{m}^{3} / \mathrm{h}$ ) was measured within the pressure range of 200 and $300 \mathrm{kPa}$ and represented as pressure head (h in $\mathrm{m})$ and both formulated in a power relationship as :

$$
\mathbf{q}=\mathbf{0 . 1 2 8} \sqrt{\mathbf{h}}
$$

Discharge in $\mathrm{m}^{3} / \mathrm{h}$ and diameter of throw in meters were measured at 200 and $300 \mathrm{kPa}$ operating pressure. Coefficient of discharge was found 0.952. Sprinkler discharge was increased by increasing pressure. The mean of the application rate (AR in $\mathrm{mm} / \mathrm{h}$ ) was recorded for individual sprinkler and increased by increasing water pressure due to increasing discharge and decreased by increasing sprinkler pattern diameter. The discharge was unchanged by trajectory angle (changed $25^{\circ}$ and $11^{\circ}$ ). But mean of application rate was increased by decreasing trajectory angle due to decreasing of sprinkler pattern diameter.

Sprinkler application rate as found by sprinkler radial test as related to distance from individual sprinkler for each nozzle was presented in all figures. For sets of range $11^{\circ}$ and $25^{\circ}$, the curves produced under medium pressure of $200 \mathrm{kPa}$ showed that, water from nozzle settled around sprinkler and smoothly dropped from start to end of water trajectory. Curves under $200 \mathrm{kPa}$ were profiled as type C. For high pressure of $300 \mathrm{kPa}$, water patterns showed semi-trapezoid shape and a mixed type in between curves $C$ and $D$ as presented in table (1) in nozzle \#8 and \#3. Under high pressure, the shape of the curves was typed as $\mathrm{E}$ profile. Selecting the optimal operating pressure based on the shape of the curve, $300 \mathrm{kPa}$ for most sets could be the required value.

\subsection{Performance parameters for sprinkler with different layouts}

Table 3 represents a group of sprinklers performance simulated in square layout under different pressures and trajectory angles $25^{\circ}$ and $11^{\circ}$, for each nozzle spaced as 50\% from throw diameter and 100\% overlapping. Data in Table 3 were collected for all nozzles from sprinkler layout at different operating pressures headed in square corners based on $100 \%$ overlapped percentage (50\% from diameter or head to head). Mean application rate (AR in $\mathrm{mm} / \mathrm{h}$ ) was determined based on collected depths as cumulated from water distribution pattern. Mean (AR) was increased by operating pressure and decreased by increasing layout area. Coefficient of variation (CV) was calculated in each set and achieved a 
low value of $6.14 \%$ at optimal operating pressure of $300 \mathrm{kPa}$ for $25^{\circ}$ trajectory angle. $(\mathrm{CV})$ values at $300 \mathrm{kPa}$ in nozzles ranging from 4.35 to $29.24 \%$ ere insignificant at $8 \%$ level. However, it was significantly different in some nozzles. The values of (CV) at $200 \mathrm{kPa}$ and $300 \mathrm{kPa}$ were highly significant at $8 \%$ level. The optimal operating pressure was recommended as $300 \mathrm{kPa}$. Uniformity coefficient $(\mathrm{CU})$ as a function of coefficient of variation achieved high value at $300 \mathrm{kPa}$ for sprinkler in nozzle ranging from \#3 to \#8.

For all nozzles of sprinkler and trajectory angle, ranging from $11^{\circ}$ to $25^{\circ}$ under $300 \mathrm{kPa}$ of optimal operating pressure, the effective diameter of throw was chosen to create different spacing between sprinklers and overlapped percentages as shown in Table 3 for square layout and Table 4 for rectangular layout and Table 5 for triangular layout. Area saved by four sprinklers and operated at less than $300 \mathrm{kPa}$ of operating pressure was related only to wetted diameter. Wetted diameter was constant for each test. The discharge of each sprinkler was not changed under $300 \mathrm{kPa}$, application rate (AR) was only decreased by increasing the served area and vice versa. Application rate $(\mathrm{mm} / \mathrm{h})$ could be used for purpose of schedule and management of sprinkler system with the tested head as described before in material and methods. For a nozzle in square layout Table 3, a high degree of uniformity was achieved for $11^{\circ}$ trajectory angle in nozzle \#3. But such close spacing raised both application rate runoff and system cost. For purpose of changing trajectory angle range $11^{\circ}$ and $25^{\circ}$ achieved acceptable uniformity as 96.57 and $96.53 \%$ in square layout for 80 and100 overlapped percentages. For purpose of increasing sprinklers spacing and trajectory angle, acceptance uniformity was achieved as more than $80 \%$ using spacing as $60 \%$ of wetted diameter ( $80 \%$ of overlapping). For hydraulic variation $10 \%$, more than $80 \%$ of uniformity was accepted for general crops and greater than $90 \%$ for high value crops. System cost could be lowered by using sprinklers spacing as $70 \%$ from diameter of throw for general crops as in $(50 \%$ of overlapping) . As most of water distribution patterns were profiled as $\mathrm{C}$ and D typed (Table 1), therefore, results of recommended spacing in this work were harmonized with those reported by Keller and R.D.Bliesner(1990). 


\begin{tabular}{|c|c|c|c|c|}
\hline \multirow{3}{*}{$\begin{array}{c}\text { Pressure } \\
(\mathrm{kPa})\end{array}$} & \multirow{3}{*}{ Parameters } & \multirow{3}{*}{$\begin{array}{l}\text { Nozzle } \\
\quad \# 8\end{array}$} & \multicolumn{2}{|c|}{ Nozzle \#3 } \\
\hline & & & \multicolumn{2}{|c|}{ Trajectory angle } \\
\hline & & & $25^{\circ}$ & $11^{\circ}$ \\
\hline \multirow{5}{*}{200} & Served area $\left(\mathrm{m}^{2}\right)$ & 144.00 & 144.00 & 64.00 \\
\hline & Application rate, $\mathrm{AR},(\mathrm{mm} / \mathrm{h})$ & 7.90 & 2.83 & 7.50 \\
\hline & Coefficient of variation, $\mathrm{CV},(\%)$ & 26.00 & 23.10 & 22.00 \\
\hline & Coefficient of uniformity,CU, (\%) & 74.00 & 76.90 & 78.00 \\
\hline & Distribution uniformity, DU,(\%) & 58.62 & 63.24 & 64.99 \\
\hline \multirow{5}{*}{300} & Served area $\left(\mathrm{m}^{2}\right)$ & 256.00 & 144.00 & 100.0 \\
\hline & Application rate, $\mathrm{AR},(\mathrm{mm} / \mathrm{h})$ & 5.72 & 3.42 & 5.06 \\
\hline & Coefficient of variation, CV, (\%) & 23.33 & 14.25 & 8.39 \\
\hline & Coefficient of uniformity,CU, (\%) & 76.67 & 85.75 & 91.61 \\
\hline & Distribution uniformity, DU, $(\%)$ & 62.87 & 77.32 & 86.65 \\
\hline
\end{tabular}

Table 4 represents a group of sprinklers performance simulated in square layout at $300 \mathrm{kPa}$ of operating pressure under different overlapped percentages and trajectory angle $25^{\circ}$ for all nozzles and trajectory angle $11^{\circ}$, for nozzle \#8and \#3.

Table 4: A group of sprinklers performance simulated in square layout at $300 \mathrm{kPa}$ of pressure under different overlapped percentages.

\begin{tabular}{|c|c|c|c|c|}
\hline \multirow{3}{*}{$\begin{array}{l}\text { Overlappin } \\
\qquad \begin{array}{c}\mathrm{g} \\
(\%)\end{array}\end{array}$} & \multirow[t]{3}{*}{ Parameters } & \multirow[t]{3}{*}{ Nozzle \#8 } & \multicolumn{2}{|c|}{ Nozzle \#3 } \\
\hline & & & \multicolumn{2}{|c|}{ Trajectory angle } \\
\hline & & & $25^{\circ}$ & $11^{\circ}$ \\
\hline \multirow{5}{*}{100} & Served area $\left(\mathrm{m}^{2}\right)$ & 256.00 & 144.00 & 100.00 \\
\hline & Application rate,AR,(mm/h) & 5.72 & 3.42 & 5.06 \\
\hline & Coefficient of variation, $\mathrm{CV},(\%)$ & 23.33 & 14.25 & 8.39 \\
\hline & Coefficient of uniformity,CU, (\%) & 76.67 & 85.75 & 91.61 \\
\hline & Distribution uniformity, DU, $(\%)$ & 62.87 & 77.32 & 86.65 \\
\hline \multirow{5}{*}{80} & Served area $\left(\mathrm{m}^{2}\right)$ & 368.60 & 207.40 & 144.00 \\
\hline & Application rate, $\mathrm{AR},(\mathrm{mm} / \mathrm{h})$ & 3.97 & 2.37 & 3.51 \\
\hline & Coefficient of variation, CV, $(\%)$ & 19.86 & 10.00 & 11.82 \\
\hline & Coefficient of uniformity,CU, (\%) & 80.14 & 90.00 & 88.18 \\
\hline & Distribution uniformity, DU,(\%) & 68.39 & 84.09 & 81.19 \\
\hline
\end{tabular}


Served area $\left(\mathrm{m}^{2}\right)$, application rate $(\mathrm{mm} / \mathrm{h})$, coefficient of variation $(\mathrm{CV})$, uniformity coefficient (CU) and distribution uniformity (DU) were calculated and listed in Table 4.

Table 5 represents a group of sprinklers performance simulated in triangular layout at $300 \mathrm{kPa}$ of operating pressure under different overlapped percentages and trajectory angle $25^{\circ}$ for all nozzles and trajectory angle $11^{\circ}$, for nozzle \#8and \#3. Served area $\left(\mathrm{m}^{2}\right)$, application rate $(\mathrm{mm} / \mathrm{h})$, coefficient of variation $(\mathrm{CV})$, uniformity coefficient $(\mathrm{CU})$ and distribution uniformity (DU) were calculated and listed in Table 5.

Table 5: A group of sprinklers performance simulated in triangular layout at $300 \mathrm{kPa}$ of pressure under different overlapped percentages.

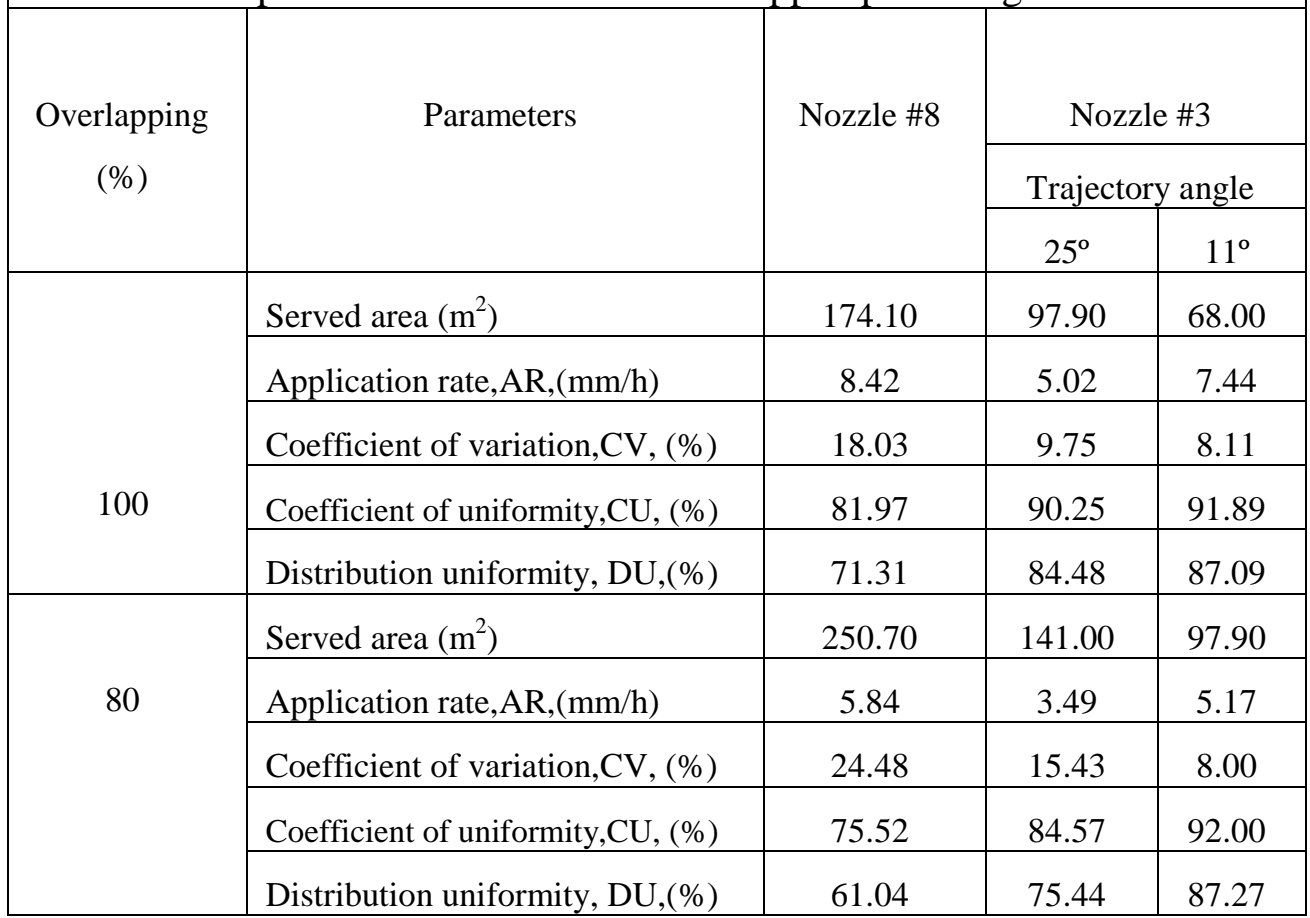

For $100 \%$ overlapping, $\geq 90 \%$ of uniformity coefficient (CU) was achieved for trajectory angle ranged from $11^{\circ}$ to $25^{\circ}$ for all nozzles and trajectory angle and $\geq 71 \%$ of (CU) for nozzles \#8, \#6 and \#4 which achieved $<71 \%$. For $80 \%$ overlapping, all nozzles achieved more than 
$72 \%$ at trajectory angle $11^{\circ}$ and $25^{\circ}$. For low angle and low overlapping percentages in triangular layout, a high uniformity degree was obtained compared to square layout. Results of recommended spacing in this work were harmonized with those reported by Keller and R.D.Bliesner(1990).

Table 6 showed a group of sprinklers performance simulated in rectangular layout at $300 \mathrm{kPa}$ of operating pressure under different overlapped percentages and trajectory angle $25^{\circ}$ for all nozzles and trajectory angle $11^{\circ}$, for nozzle \#8and \#3. Served area $\left(\mathrm{m}^{2}\right)$, application rate $(\mathrm{mm} / \mathrm{h})$, coefficient of variation $(\mathrm{CV})$, uniformity coefficient $(\mathrm{CU})$ and distribution uniformity (DU) were calculated and listed in Table 6.

Table 6: A group of sprinklers performance simulated in rectangular layout at $300 \mathrm{kPa}$ of pressure under different overlapped percentages.

\begin{tabular}{|c|c|c|c|c|}
\hline \multirow{4}{*}{$\begin{array}{l}\text { Overlapping } \\
(\%)\end{array}$} & \multirow{4}{*}{ Parameters } & \multirow{4}{*}{$\begin{array}{c}\text { Nozzle } \\
\text { \#8 }\end{array}$} & \multirow{2}{*}{\multicolumn{2}{|c|}{ Nozzle \#3 }} \\
\hline & & & & \\
\hline & & & \multicolumn{2}{|c|}{ Trajectory angle } \\
\hline & & & $25^{\circ}$ & $11^{\circ}$ \\
\hline \multirow{5}{*}{100} & Served area $\left(\mathrm{m}^{2}\right)$ & 307.00 & 173.00 & 120.00 \\
\hline & Application rate, $\mathrm{AR},(\mathrm{mm} / \mathrm{h})$ & 4.77 & 2.85 & 4.22 \\
\hline & Coefficient of variation, $\mathrm{CV},(\%)$ & 34.07 & 23.60 & 27.16 \\
\hline & Coefficient of uniformity,CU, (\%) & 65.93 & 76.40 & 72.84 \\
\hline & Distribution uniformity, DU,(\%) & 45.78 & 62.44 & 56.78 \\
\hline \multirow{5}{*}{80} & Served area $\left(\mathrm{m}^{2}\right)$ & 372.50 & 210.20 & 146.40 \\
\hline & Application rate, $\mathrm{AR},(\mathrm{mm} / \mathrm{h})$ & 3.93 & 2.34 & 3.46 \\
\hline & Coefficient of variation, $\mathrm{CV},(\%)$ & 42.56 & 32.26 & 34.12 \\
\hline & Coefficient of uniformity,CU, (\%) & 57.44 & 67.74 & 65.88 \\
\hline & Distribution uniformity, DU, $(\%)$ & 32.27 & 48.66 & 45.70 \\
\hline
\end{tabular}

In rectangular layout, the overlap of $100 \%$ achieved low coefficient of variation and high uniformity. For a given overlapped percentages, the 
higher degree of uniformity was achieved for $11^{\circ}$ trajectory angle in nozzle \#3. For $100 \%$ overlapping, $\geq 80 \%$ of uniformity coefficient (CU) was achieved for trajectory angle ranged from $11^{\circ}$ to $25^{\circ}$, nozzle \#3 at $11^{\circ}$ trajectory angle and $<78 \%$ of $(\mathrm{CU})$ for nozzles \#8. For $80 \%$ overlapping, all nozzles achieved more than $57 \%$ at trajectory angle $11^{\circ}$ and $25^{\circ}$ which was not recommended.

Friction factor which gives accurate prediction for friction head loss for a given pipe length with a constant input and output discharge sprinkler has been estimated for the design to reach the optimal inner diameter for main, sub main and lateral lines under optimal nozzle, trajectory angle, pressure, layout and overlapping. Area $\left(6655 \mathrm{~m}^{2}\right)(55 \mathrm{~m}$ wide $\times 121 \mathrm{~m}$ length), 72 sprinklers were used and 12 lateral lines with (20 and $25 \mathrm{~mm})$ inner diameter and 4 sub main lines $(50 \mathrm{~mm})$ inner diameter and single inlet main line $(62 \mathrm{~mm})$ inner diameter. The water source position with $10 \mathrm{~m}^{3} / \mathrm{h}$ at half for main line and distance from the source to the last sprinkler (critical length) $115.5 \mathrm{~m}$. The area were blocked to four blokes, each had one valve and one sub main and three lateral lines and 15 sprinklers and all lines were made from (PVC). The system used nozzle \#3 trajectory angle $25^{\circ}, 0.5 \mathrm{~m}^{3} / \mathrm{h}$ discharge with wetted diameter $22 \mathrm{~m}$ , $300 \mathrm{kPa}$ operating pressure, square layout and $100 \%$ overlapping percentage.

\section{CONCLUSSION}

Performance of sprinkler pattern radius and uniformity tests were carried out and evaluated at Shibin El-Kom, faculty of Agriculture, Menoufiya University, Egypt. K-rain Rps 75 pop up sprinklers were selected due to having 12 nozzles with different configurations where, trajectory angle of eight nozzles is $25^{\circ}$ and four nozzles is $11^{\circ}$. Water distribution pattern was determined at 200 and $300 \mathrm{kPa}$ of operating pressure for nozzle \#8 and nozzle \#3 of sprinkler. Proper operating pressure was $300 \mathrm{kPa}$ for nozzles trajectory angle $25^{\circ}$. At operating pressure $300 \mathrm{kPa}$, the application rate in $(\mathrm{mm} / \mathrm{h})$ distributed as bell shape in wetted cycle of the 
individual test for nozzle \#8 and trajectory angle $25^{\circ}$ of sprinkler with $32 \mathrm{~m}$ diameter and considered as good distribution. The spacing between sprinklers was considered, to be based on the results, as $50 \%$ from wetted diameter. Coefficient of variation, (CV) was calculated in each test and its low value of $6.14 \%$ was occurred at optimal operating pressure of $300 \mathrm{kPa}$ for $25^{\circ}$ trajectory angle. The values of $(\mathrm{CV})$ at $200 \mathrm{kPa}$ were found highly significant at $8 \%$ level. Uniformity coefficient (CU) as a function of coefficient of variation achieved high value at $300 \mathrm{kPa}$. Triangular layout test achieved higher distribution of uniformity more than both square and rectangular layouts. Square layout test achieved higher distribution of uniformity than rectangular layout for 100 and $80 \%$ overlapping. Friction factor which gives accurate prediction for head, friction head for a given pipe length with a constant input and output sprinkler discharge has been estimated for design to reach the optimal inner diameter for main, sub main and lateral lines under optimal nozzle, trajectory angle, operating pressure, layout and overlapping. Area of $\left(6655 \mathrm{~m}^{2}\right)(55 \mathrm{~m}$ wide $\times 121 \mathrm{~m}$ length $)$, and 72 sprinklers were used.

\section{REFERENCES}

Aboamera, M.A, and H.Sourell (2003). Characteristics of water distribution and irrigation intensity for floppy sprinklers. The $11^{\text {th }}$ Annual Conference of Misr Society of Agric., Eng., Egypt, 1516Oct.,20(4) : 937-948.

Anonymous,(1995). Agricultural irrigation equipment. Rotating sprinklers . Part 1. Design operational requirements. ISO Standard 7749/1. ISO, Geneva. Switzerland

Amr,K.H.(2006).Water Distribution Uniformity As Affected By Sprinkler Performance. Misr J.Ag.Eng.,23(1):66-79.

Ascough,G.W.,andG.A.Kiker(2002).The effect of irrigation uniformity on irrigation water requirements. Water ASA, 28(2): 235-241. 
Christiansen,J.E.(1942). Irrigation by sprinkling. California Agric. Exp.Sta., Bull. 670.,124p University of California .Berkeley, California.

Ducks, M.D. and C.Perry (2006). Uniformity testing of variable-rate center pivot irrigation control systems. Precision Agriculture, 7(3):205-218.

El-Awady,M.N.,E.G.Vis, R.Kumar.,and S.Mitra (2003). Distribution uniformity from pop - up sprinklers and landscape water -saving. The $11^{\text {th }}$ Annual Conf., MSAE, Kafr ElSheikh,Egypt: 181-194.

El-Sherbeni,A.M.(1994). Design of sprinkler and drip irrigation systems in newly reclaimed soils. Unpublished Ph.D. Thesis in Agric.,Eng., Faculty of agriculture, Zagazig university, Egypt,141P.

Hegazi,M.,K.H.Amr and H. Moghazy (2007). Sprinkler Irrigation System Layout Based On Water Distribution Pattern.

Irrigation Training and Research Center ITRC(1991).Landscape water management principles. Version 1,01, Cal Poly State University, San Luis Obispo, California, HOP.,C.F.

Keller, J., and R.D.Bliesner (1990). Sprinkler and Trickle Irrigation. New York, N.Y:Van Nostrand Reinhold.

Li,J., and H.Kawano (1998). Sprinkler performance as affected by nozzle inner contraction angle. Irrig. Sci., 18:63-66.

Warrick,A.W.,and M.Yitayew (1988). Trickle lateral hydraulic. L., Analytical solution, J. Irrig. and Drainage, ASCE 114(2):281-288.

Waters,G.Z., and J.Keller (1978). Trickle irrigation tubing hydraulics. ASAE Paper 78-2015.

Zanon,E.R., R.Testezlaf, and E.J.Matsura (2000).a data acquisition system for sprinkler uniformity testing. Applied Engineering in Agriculture of the ASAE 16(2): 123-127. 


\section{الملخص العربي \\ تصميم وتقييم نظام ري بالرش بناء على الانتظامية}

د/ كمال حسنى عامر (') د/ محمد على أبوعميرة (') د/ أحمد حسن جمعة (') م/صبحي بهنسى(") أجريت هذه التجربة بمزرعة كلية الزر اعة جامعة المنوفية بمدينة شبين الكوم واستهدفت دراسة

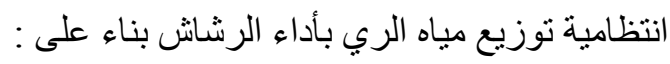

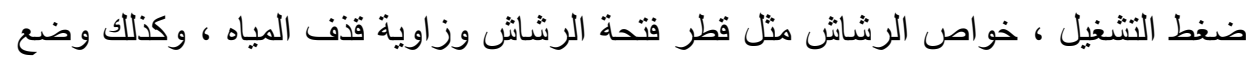

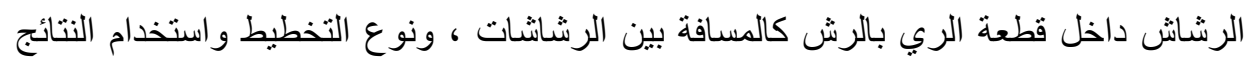

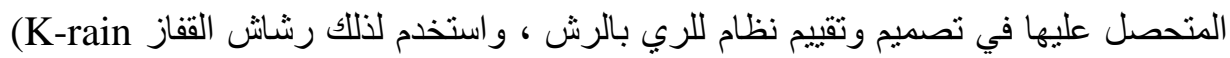
يحتوى على ثلاثة فو هات يعطى كل منها تصرف مختلف ودائرة ابتلال مختلفة .

و هذا النوع من الرشانشات يمتاز بإمكانية تغيير فوهة الرش فالثلاث فوهات المستخدمة اثنتان

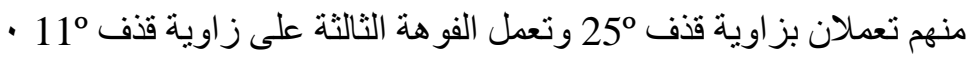
ولتحقيق الهدف من الدراسة نم إجراء تجربة لتحديد شكل ومدى قذف المياه من الرشاش على التى

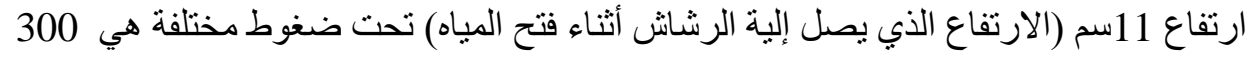

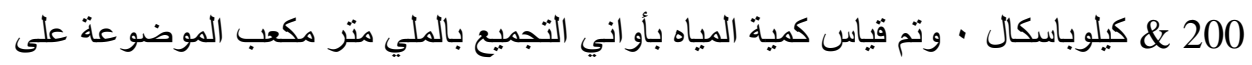

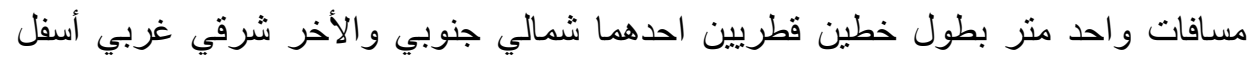

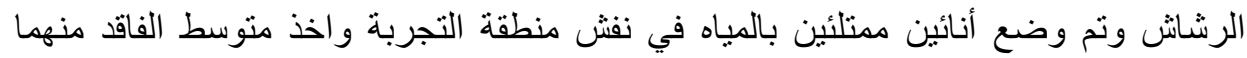

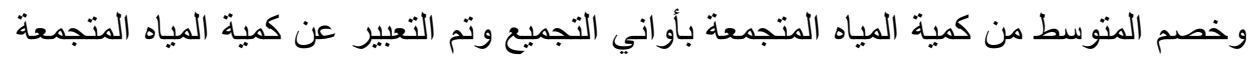

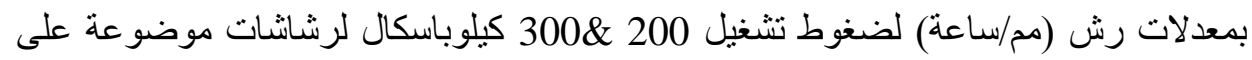
رؤوس مربع طول ضلعة يساوى 50\% من قطر القذف (100\% التداخل) لتحديد ضغط التشغيل

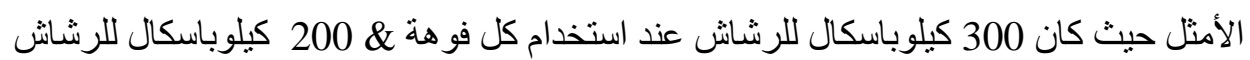

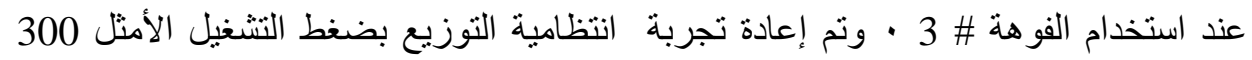
كيلوباسكال لنسب تداخل هي 100\% \& 80\% لثلاثة أنواع من التخطيط هي المربع و المثلث

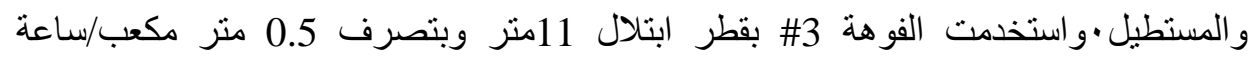

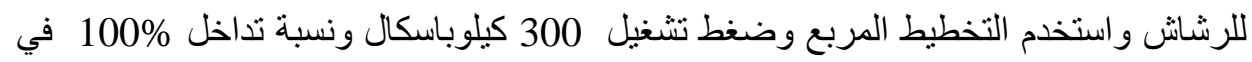

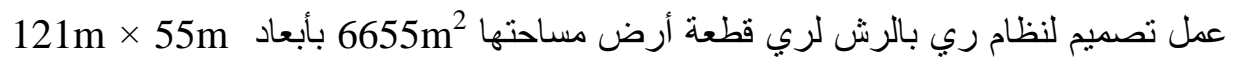
باستاد جامعة المنوفية وتكون نظام الري من خط رئيسي بطول 100 متر وبقطر داخل داخلي 62 مم

(') (أستاذ مساعد بقسم الهندسة الزراعية كلية الزراعة جامعة المنوفية

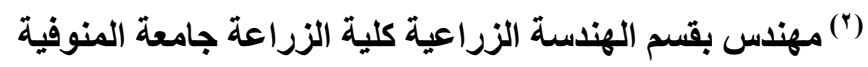


ومصدر المياه يتوسط الخط وبتصرف كلى 9 متر مكعب/ساعة ويغذى أربعة خطوط ري تحت رئيسية بطول 22 منر وقطر داخلي 50 مم وكل خط ري تحت رئيسي يخرج منة ثناثة خطوط ري فرعية بطول كلى 55 منر ( 33 منر بقطر داخلي 25مم وبتصرف متوسط 2 منر مكعب/ساعة \& 22 منر بقطر داخلي 20مم وبتصرف منوسط 1 منر مكعب/ساعة) و عد ستة رشاثـات قفاز لكل خط ري فرعى وتم حساب الطول الحرج وحساب قيمة معامل الاحتكاك داخل الأنابيب للوصول إلى أنسب قطر داخلي لكل من خط الري الرئيسي وخطوط الري التحت وحت

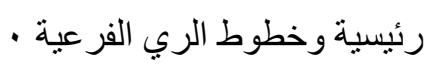
وتوصلت الدر اسة إلى النتائج الآتية: -1 - أعلى انتظامية توزيع تم الحصول عليها عند ضغط 300 كيلوباسكال للرشاش ذو الفوهة وبز اوية قذف $25^{\circ}$ وذلك لكل من التخطيط المربع و المستطيل. -2- التخطيط المربع حقق أعلى انتظامية توزيع مقارنة بالتخطيط المستطيل وذللك عند قيمتي

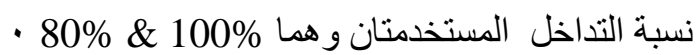
-3- فاقد الاحتكالك لطول معين من خط الري استخدم في تصميم أقطار خط الري الرئيسي و الخط تحت الرئيسي والخط الفرعي عند زاوية القذف المثلي و الضغط و التخطيط الأمثل و القيمة

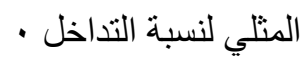

